Article

\title{
Readjusting imagined markets: morality and institutional resilience in the German and British bank bailout of 2008
}

\author{
Sascha Münnich* \\ Georg-August-University Göttingen, Institute of Sociology, Göttingen, Germany \\ *Correspondence: sascha.muennich@sowi.uni-goettingen.de
}

\begin{abstract}
Why was there no fundamental change of financial regulation after the 2008 credit crunch? This article argues that the limited regulatory changes of German and British financial markets can be explained by the influence moral boundaries between legitimate and illegitimate financial practices had on policymakers' crisis perception. In German public debate of 2008, speculation as opposed to firm investment was seen as cause of the crisis. The British crisis narrative held illegitimate profits responsible that were gained from excessive risk-taking as opposed to risk management. These distinct legitimizing patterns (a) fostered a selective perception of the crisis that downplayed domestic structural causes of the crisis, and (b) directed regulatory efforts away from fundamental reforms. In fact, both national debates saw the institutional regime of their financial markets re-affirmed by the crisis and in need of readjustment. Conceptually, the article shows the affinity between public moral boundaries of legitimate economic practices and the core institutional principles of market regimes.
\end{abstract}

Key words: institutional change, discourse, financial crisis, varieties of capitalism, culture, path dependence

JEL classification: P16 political economy, P52 comparative studies of particular economies, G21 banks, depository institutions, micro finance institutions, mortgages

\section{Introduction}

The banking crisis of 2007-2008 triggered a new wave of public anti-capitalism that stands in remarkable contrast to the global triumph of financial capitalism since the end of the Cold War. Until today, in public debates capitalism is seen at a 'moral dead-end' (The Observer, 4/4/2010, p. 23) or in a 'moral crisis' (Financial Mail, 4/7/2013). Even conservative journalists 
timidly ask 'Is the Left right after all?' (The Telegraph, 7/22/2011; Frankfurter Allgemeine, $8 / 15 / 2011$ ). Criticizing capitalism seems to be fashionable again across all political camps. From a social science perspective, there can be little doubt that the fall of 2008 could be seen as a critical moment, in which radical state intervention could have ended a 30 -year period of success for liberal financial capitalism. The economic scope of the crisis is beyond doubt. All industrialized countries had to put substantial parts of their GDP at risk to bail out their largest banks and re-inject liquidity into the markets (see figures in Culpepper and Reinke, 2014, p. 444). All European countries faced a severe economic downturn in the aftermath of the crisis, with some of them, like Greece or Spain, still struggling with recession and social turmoil to the present day. Moreover, the bailout interventions were staggering breaks from the established paths of policy-making. We have seen the supposedly market-friendly British government nationalizing a substantial part of their banking sector overnight, as well as the supposedly consensus-oriented German government unilaterally covering billions of financial losses. This is far away from German 'patient capital' or British 'free capital' strategies of the past. Therefore, the window of opportunity for fundamental regulatory change should have been wide open. As of today, however, we have seen only a modest adjustment of capital market regulation, marked by the new Basel III capitalization rules and a gradual reform of banking oversight in the EU. In contrast to the often-cited parallels to the 1930s, no larger country has witnessed a fundamental restructuring of the financial sector or banking industry. Once again, institutional change has proven to be slow and gradual (Mayntz, 2013, pp. 14-17).

Since the banking crisis of 2007/2008, researchers concerned with ideas in economic policy-making are puzzled why there was no 'third-order change' of policy (Hall, 2013, 1993). Why did governments miss this chance for paradigmatic reform? A classical state capitalism approach would hold the power of financial interests accountable: in face of an existential threat to capitalism all necessary state measures were taken to rescue banks-and their profits. After the turmoil has been contained, however, neoliberalism is now back in the saddle. Some authors have described the encounter of state and financial interests in the crisis in detail. They show that the cost sharing of the bank-bailout reflected the structural political power of the financial sector, as well as the power balances between international and domestic banks (Culpepper and Reinke, 2014; Grossman and Woll, 2014).

However, from an institutionalist point of view, this explanation is somewhat dissatisfying. Over many years, historical institutionalists working on modern (welfare) state building have taught us that public administration should be treated as an independent explanatory factor. Political and administrative elites exceed an autonomous action capacity, especially during a time of crisis (Skocpol and Finegold, 1982; Evans et al., 1985; Weir and Skocpol, 1985; Hall, $1989 b$ ). To understand which 'national interest' autonomous officials were pursuing, later scholars turned towards the influence of ideas on policy-making (Heclo, 1974; Berman, 2013 , p. 219). Thus, the unsettling question is: does the lack of change in the financial crisis prove the concept of autonomous administrative capacity wrong?

In this article, I am arguing that this is not the case. Instead, I will show that the lack of fundamental regulatory reforms in the credit crunch can be explained by taking into account how normative ideas about legitimate and illegitimate banking distorted the crisis perception of policymakers in their great moment of autonomy. The strange ambivalence of the bank bailout policies-minimum regulatory change and maximum fiscal intervention-could be explained as an episode of idea-shaped administrative autonomy. In their ambition to 
quickly make sense of a complex and uncertain situation policymakers' crisis perception was informed, or even distorted by culturally specific normative boundaries between legitimate and illegitimate profit seeking. These boundaries shaped to which degree and at which points policymakers saw their national financial systems in crisis. However, because those moral boundaries had also historically served as legitimizing principles of their national financial market regimes, they drove fundamental restructuring of financial market regulation off the political agenda, turning the crisis reaction into a readjustment of national regimes.

Looking at two very distinct financial regimes, Germany and the UK, I conducted a content analysis of parliamentary proceedings and newspaper articles, seeking all statements of government officials, party leaders, heads of trade unions and employer associations, as well as public economists and financial market actors in the early weeks after the Lehman breakdown. The guiding methodological principle was to track down all public statements by actors who had high relevance for any advocacy coalition for or against financial market reform (Jenkins-Smith and Sabatier, 1993). The analysed statements cut across all political camps in order to show to which degree the two debates were influenced by shared definitions of moral boundaries between legitimate and illegitimate profit seeking. UK policymakers turned towards singling out incompetent market actors and strengthening the market principles of competition and meritocracy. German policymakers wanted to penalize the banking sector as a whole for engaging in speculative action instead of supporting national growth. In both countries, these moral boundaries set the path towards an affirmation of national financial regimes even though it was apparent that both regimes had — to say the least — provided no safeguard against the crisis. The material presented here provides evidence for the conceptual argument that institutionally privileged normative ideas influence the change of those institutions that carry them. They provide a discursive lens through which reform efforts were framed as 'forcing the system back to its original purpose'. Political debates stick to their institutional regimes even in the face of their obvious failure. Here my argument shares a perspective with recent studies of the European financial and sovereign debt crisis, which have pointed towards the resilience of ideological motives, such as austerity and neoliberalism, as an explanatory factor for the lack of institutional change in the crisis (Blyth, 2013a; Schmidt and Thatcher 2013).

The argument will proceed in three steps: first, I will develop a conceptual framework of moral boundaries of legitimate profit seeking and their relation to economic crisis perception and institutions; second, the 2007/2008 crisis and the unfolding of the public bailout debates in Germany and the UK will be examined to describe their normative distortion of the two debates; third, it will be discussed how public crisis perception drew attention away from market re-structuring; a conclusion will sum up the argument concerning the interplay of ideas and institutions for the legitimacy of economic orders.

\section{Morality and institutions in financial crises}

In order to explain the selectivity of the crisis narrative and the lack of fundamental institutional change, it is necessary to address two conceptual issues concerning the role of ideas in institutional change: first, the interplay of normative and cognitive ideas, of morality and knowledge, in crisis perceptions and its consequences for political learning; and second, the problem that ideas influence institutional change while at the same time their discursive power depends on institutions. 


\subsection{Crisis perception and the moral dimensions of finance}

Ideas can be found at all stages and on all levels of political interaction. Policymakers have to publicly justify their ambitions in regard to definitions of the common good and legitimate ways to reach it. There are many different concepts by which ideas have been operationalized for institutional change: road maps (Goldstein and Keohane, 1993), collective action frames (Benford and Snow, 2000), blue prints (Steinmetz, 1993), cultural tools (Swidler, 1986) or focal points (Ringe, 2005) - just to mention a few. One of the most-often cited dimensions of the concept is the distinction between cognitive and normative ideas (Braun, 1999; Campbell, 2004): ideas can mean knowledge about the causal relations and problems or normative evaluations of ends and means. Although it is analytically helpful to differentiate between ideas on how the world is and how it should be these dimensions can never be fully separated, not even within economic theory (Hirschman, 1986).

The interpenetration of morality and cognition is particularly salient in financial markets. Credit relations always define power imbalances that have moral implications, which may at any point come to the discursive forefront, particularly in the case of a default or systemic crisis (Graeber, 2011; Fourcade et al., 2013). As de Goede has shown, the creation of a legitimate market for financial futures and derivatives in the US and UK depended on the introduction of a moral boundary between (illegitimate) gambling and (legitimate) financial speculation. There was a need to create a naturalized notion of economic risk as a substantial aspect of any enterprise that always has to be borne by some economic actor. The older moral boundary between gaining from work and gaining from gambling was re-produced within financial markets on the basis of this naturalized cognition of the economy as a nexus of risks, allowing for a differentiation of legitimate risk trading, rooted in the hard work of rational calculation of the real economy, and illegitimate gambling on 'blind chance' (de Goede 2005, pp. 47-91). Thus, the transformation of moral categories into cognitive classifications lies at the heart of modern financial markets.

The interconnectedness of norms and cognitions in financial market regulation has implications for the concept of political learning (Hall, 1993, p. 276). As Blyth pointed out, there are two ways of understanding political learning, both of which can be found in Hall's work $(2013 b)$. On the one hand, there is 'Bayesian' learning, which means that political actors react to objective problems and update their rationales accordingly (p. 198). In this understanding, knowledge of the world is cumulative and based on experience of failure and 'collective puzzlement' (Hall, 1993, p. 276). For example, from this perspective the dominant economic policy paradigm changed to Keynesianism because of the failure of classical liberalism to explain the Great Depression. Again, it switched to Monetarism in the late 1970s because of Keynesians' inability to explain stagflation and the failure of macroeconomic governance. For our question, this means that different cognitions and norms may become influential because they are more adequate responses to economic crises.

But there is also a second, 'constructivist' concept of political learning. Here, ideas do not only influence which solution or response is given to a problem, but they already shape actors' perception of the problem itself and their interests in it. This refers back to a famous example for the subjectivity of knowledge by Alfred Schutz: 'Both attempts, to induce rain by performing the rain-dance or by seeding clouds with silver iodine, are subjectively seen, rational actions from the point of view of the Hopi Indian or the modern meteorologist, respectively' (Schutz, 1962, p. 29). Puzzling consists of a selective construction of the problem by taking out a piece of reality as relevant. Policymakers in a crisis face uncertainty, in which 'agents can 
have no conception as to what possible outcomes are likely, and hence what their interests in such a situation in fact are. [. . .] complex set of ideas [. . . ] allow agents to order and intervene in the world. [. . .] Only then can agents diagnose the crisis they are facing' (Blyth, 2002, p. 32). There is a demand and a supply side of political learning (Berman, 2013), and from this view also the demand side is shaped by ideas.

However, there is a deeper problem within a constructivist concept of political learning that refers to the entanglement of knowledge and normative ideas: already the political perception of a crisis may be subject to normative filtering, among political actors as well as for the audience they are addressing. If this is true, learning may only take place in regard towards those aspects of a crisis that are normatively privileged. In the case of financial markets, the culturally and historically specific moral boundary between legitimate and illegitimate speculation may influence how actors perceive the functioning and crisis of financial markets. All knowledge would to a certain degree be culturally indexed, with a distinct normative focus of a national political discourse that allows for only a reduced range of questions that can legitimately be asked and problems that may be raised. I will show that such moral ideas in Germany and UK influenced the crisis perception of policymakers and the wider public debate. By privileging a crisis narrative that centered on illegitimate profit seeking, they ignored some of the most relevant domestic dimensions of the crisis.

\subsection{Institutionally privileged ideas and levels of institutional regulation}

Even if we agree that the crisis perception is normatively filtered this may explain selective regulatory action rather than a total lack of change. In order to understand why the normative selectivity of the public debate blocked fundamental institutional change, it is necessary to more closely examine the relation of morality and financial market institutions. In her definition of 'discursive institutionalism' Schmidt claims that scholars from all three camps of institutionalism (Hall and Taylor, 1996) have struggled with the question to which extent institutions shape ideas and vice versa (Schmidt, 2010, 2008). This problem is already present in Peter Hall's seminal studies of economic policymaking (Berman, 2013, p. 220). On the one hand, Hall stresses the influence of institutions on ideas: 'If the Keynesian case demonstrates that ideas have real power in the political world, however, it also confirms that they do not acquire political force independently of the constellation of institutions and interests already present here.' (Hall, 1989a, p. 390) On the other hand, in his later work he puts emphasis on ideas as independent explanatory factors for third-order change. If the 'overarching goals that guide policy in a particular field' are changed (Hall, 1993, p. 278), this change will often be accountable to 'radical changes in the overarching terms of policy discourse' (p. 279).

The lack of a clear-cut conceptual distinction between ideas and institutions can also be observed in the competing positions of historical and sociological institutionalists in regard to institutional change (Thelen, 2003; Hacker, 2004). Sociological institutionalism (SI) treats institutions as cognitive and normative templates for rational action (DiMaggio and Powell, 1991). In SI 'one cannot talk about a turn to ideas as such, since ideas have always been at the basis of the approach-as norms, frames, and meaning systems' (Schmidt, 2010, p. 13). Here the core impact of institutions is the provision and injection of specific ideasworldviews and action orientations, 'conceptions of control' (Fligstein, 1996) or even 'rational myths' (Meyer and Rowan, 1991) towards which actors orient their economic behaviour. Institutions become fundamental parts of the knowledge and evaluation of actors. If, 
however, institutions are identified with subjective action orientations too closely, one may ask how change is possible, in particular, where those ideas can come from that pave the way for deviant behaviour (Beckert, 2010). To build up more analytical distance between ideas and institutions historical institutionalists have located ideas on the side of the actor who is interpreting institutional rules, identifying need for change and potentially re-framing them (Streeck and Thelen, 2005, p. 14). However, a full conceptual isolation of the normative and cognitive meaning of institutions from its rule content is implausible if it is not framed in a purely rational choice mode, in which institutions are merely cost structures. If the impact of institutions on action is instead described as 'relations of authority, obligation, and enforcement as opposed to voluntarism' (p. 14), it is hard to imagine how such a Durkheimian concept of institutions could get along without ascribing institutions normative power beyond sanctioning cost. Independent of disciplinary lines between institutionalist approaches, there seems to be little chance of easily foregoing the problem that the power of certain ideas is dependent on their institutionalization while at the same time institutional change may be informed by them.

I argue that it would be helpful if we differentiated more clearly between levels of institutional regulation, namely between core organizational principles of a market regime on the one hand, and its more practical rule content and implementation on the other side. Schmidt has operationalized this two-sided medal by defining institutions as 'structures and constructs of meaning internal to agents whose "background ideational abilities" enable them to create (and maintain) institutions while their "foreground discursive abilities" enable them to communicate critically about them, to change (or maintain) them' (Schmidt, 2010, p. 1). This argument could be understood in such a way that institutions provide meaningful action orientations that constrain action but also provide a resource for gradual regulatory change (see also Lessenich, 2005; Palier, 2005). I will show that normative ideas about legitimate financial profits, which filtered the bailout discourses of 2008 , had a strong affinity to the organizational principles of the German and British financial regimes. This will be shown by pointing out how closely related moral critique, crisis narrative and affirmation of the institutional status quo were in the public debates of the two countries. The origins of the crisis were seen in the violation of boundaries of legitimate profit seeking, which were believed to be incorporated in the core institutional principles of the two national financial market regimes.

\section{Crisis and bailout discourse in Germany}

The banking crisis of 2007/2008 was a systemic crisis rooted in the explosion of interbank lending and a steep rise of leverage ratios. It was triggered by the globalization of capital markets and state de-regulation that allowed an ever greater number of new securitized products. The global growth in size and trading frequency on financial markets created an unprecedented demand for collateral (Gorton, 2010, pp. 19-25). This was provided by the growing repo market, in which different forms of future cash flows (mortgages, credit cards, auto or student loans) became increasingly securitized, pooled and tranched. This was to a large degree executed by off-balance sheet special purpose vehicles. Most banks that engaged in derivatives trading or other credit-financed transactions relied on these markets. Gorton estimates the size of the repo market on top of the boom to be $\$ 10$ trillion, which roughly equals the total assets of the regulated US banking market (p. 44). In 2007, imbalances between securities prices and the value of the underlying assets imploded as a reaction to 
massive defaults in the American mortgage market. Highly levered institutions could not refinance themselves anymore at exploding haircuts on collateral. All ended up in a complete dry-up of markets for short-term lending. While European countries had to occasionally rescue single banks in 2007 already, the credit crunch pierced the heart of European banking after the collapse of Lehman Brothers on 15 September 2008. I will now present how public discourses unfolded between the Lehman breakdown and the bailout measures in the fall of $2008 .^{1}$

\subsection{Investment vs. speculation-normative boundaries in the public debate}

The German banking crisis hat a prelude in July 2007 with the state rescue of the German Industrial Bank (IKB), which was partially owned by the government. Its purpose had been to provide credit to small and middle-sized firms and finance mortgages. The IKB assets turned out to be highly dependent on the American subprime mortgage market, and the bank had to be bailed out with a total sum of $€ 8.5$ billion, half of which was provided by the state. Eventually the IKB was sold off to Lonestar in March 2008 for only $€ 137$ million. The German Federal government, a grand coalition of conservatives and social democrats, understood the first signs of the crisis as a signal that international financial regulation had to be improved, but no German bank bailout would be necessary. Even a few days after the Lehman collapse the German finance minister Peer Steinbrück (SPD) claimed that a bailout like in the United States would not be 'necessary and applicable' in Germany, because he saw the United States as 'cause and the most important locus of the crisis' (Deutscher Bundestag, 9/25/2008, p. 18969, see also Financial Times Deutschland, 9/24, p. 10). ${ }^{2}$ Similarly, conservative Chancellor Merkel (CDU) claimed that German regulatory efforts had been repeatedly blocked by the Anglo-American side (Chancellor Angela Merkel, Frankfurter Rundschau, 9/22, p. 13).

The early debate focused on the German social market economy as a model that is superior to laissez-faire capitalism, a perspective that was shared between conservatives and social democrats.

I explicitly share Norbert Roettgen's [Secretary of the Conservative parliamentary group] conviction that the financial crisis could in the long run globally strengthen the idea of social market economy.

(Steinbrück, Deutscher Bundestag, 9/25/2008, p. 18976)

His view was also shared by the leading opposition parties of the liberals (FDP) and the Left. MP Solms (FDP) said in the same debate: 'I believe that the social market economy will be strengthened by this crisis' (Deutscher Bundestag, 10/7/2008, p. 18980). But what exactly

1 All statements by German and British policymakers and other public commentators are taken out of two text databases: first, the proceedings of House of Commons and German Bundestag debates between the Lehman breakdown (15th September) and the passing of the bailout acts (Germany 15th October, UK 13th October). Second, direct quotations were taken from newspaper articles from the newspaper databases of Lexis Nexis for Germany and the UK. Articles were selected on the basis of their topic relevance in regard to 'financial crisis' in the LexisNexis categorization system. All statements have been coded according to four dimensions: actor/speaker, causal narrative of the crisis, proposed regulation and, if applicable, normative reference of the statement.

2 All German quotations translated by the author. 
did German policymakers mean with 'social market economy' in regard to the financial problems at stake?

To large degrees in our banking system we have deprived ourselves from an exclusive focus on short-term yields and ever-increasing quarterly profits.

(Steinbrück, Deutscher Bundestag, 10/7/2008, p. 18972)

Steinbrück set the tone for the crisis perception by drawing a boundary between legitimate long-term and illegitimate short-term investment. However, it is not only the time horizon but also the real economic impact of an investment that is crucial in the German debate. Proximity to classical 'firm investment' defines the taken-for-granted image of 'good finance' in the social market economy. Conservative MP Meister stated that good finance is about financing the real economy, especially the small and middle-sized firms (Deutscher Bundestag, 10/7/2008). He was joined by CSU conservative MP Friedrich who saw the financial crisis as a 'chance that banks in Germany could change their mind towards home credit markets, [. . .] that have a base in the solid substance of the German Mittelstand' (Deutscher Bundestag, 10/7/2008, p. 18992). Even though there was debate if state or the markets were responsible for the spread of illegitimate investment, speculative action was considered as primary cause of the crisis.

Many people who worked in banks [. . . ] were just gambling around. They played casino. And the boards of banks let them gamble because it paid off for a long time.

(Brüderle, FDP, Deutscher Bundestag, 10/7/2008, p. 18995)

With this distinction between investment and gambling Brüderle is in line with the Federal administration who took the crisis as a proof for the need to regulate against 'reinless speculation' and the need to again 'civilize' financial markets (Deutscher Bundestag, 9/25/2008, p. 18973). Kuhn, MP of the opposing Green party, called for a taxation of financial transaction with the aim of 'containing financial speculation' (Deutscher Bundestag, 10/7/2008, p. 18989) and the Chancellor repeatedly spoke about 'irresponsible speculation' in public (Deutscher Bundestag, 10/7/2008, p. 19321).

Still, in the early days after Lehman, the leading parties were convinced that the German three-layered banking system would not get into trouble (Joachim Poß, vice-chairman of the SPD parliamentary group, SZ, 9/22, p. 1) and the universal bank system would be the solution. Soon afterwards, however, it became apparent that many German banks-especially the public Landesbanken that were owned by the Laender had strongly engaged in trading toxic debt, and even the Sparkassen had sold Lehman certificates to their clients (Frankfurter Rundschau, 10/2, p. 3). On 29th September, the German government issued $€ 35$ billion of state guarantees for HRE, linked with an additional layer of $€ 26.5$ billion of direct monetary help, half of it subsidies from other banks. On 5th October, guarantees had to be raised to $€ 50$ billion. Finally, on 13th October, Chancellor Merkel announced a major bail-out for German banks with $€ 400$ billion in state guarantees- $€ 300$ billion to raise liquidity in interbank lending and $€ 100$ billion for re-capitalization.

In spite of the huge rescue efforts, the discursive structure of the debate did not change relevantly. The banking crisis was still attributed to 'irresponsible lending', primarily in the US credit market (Deutscher Bundestag, 10/7/2008, p. 19321) for which the German social market economy could provide an alternative. 
Like every crisis this financial crisis offers a chance. It offers the chance that all people inside and outside of Germany will recognize the international dimension of the social market economy, learn to understand it and claim to form it.

(Chancellor Merkel, Deutscher Bundestag, 10/7/2008, p. 19329)

The boundary between real investment and speculation remained the normative guideline for the debate. Merkel criticized financial market actors for their 'greed, irresponsible speculation and mismanagement' (Frankfurter Rundschau, 10/8, p. 13) and was joined by the opposition (Brüderle, FDP, Deutscher Bundestag, 10/7/2008, p. 18994).

We will not accept that the banking industry throws the results of their wild speculative gambling at the Federal Government's feet, but still keeps on claiming gains and future profits all for themselves.

(Fritz Kuhn, Leader of the Green Party, Frankfurter Allgemeine, 10/6, p. 1)

The government perspective was shared in the press by representatives of German private banks, who also drew the moral boundary for legitimate profits at speculation in opposition to firm investment (Louis Thannberger, Europe Finance Et, Frankfurter Allgemeine, 10/14, p. 24). Chief economist of the large private Commerzbank Jörg Krämer normatively separated investment banking from lending (Financial Times Deutschland, 9/16, p. 16). Lutz Raettig, Chairman of the Supervisory Board of Morgan Stanley Germany, publicly argued that the 'essence of financial industry is to provide capital to the economy'. He described the real investment orientation of Frankfurt banks as their international competitive advantage (Frankfurter Rundschau, 10/2, p. 3). Investment banking was considered to be the outcome of an 'unhealthy ludic drive' (Roland Berger, Management Consultant, Sueddeutsche, 10/9, p. 18). The essence of what German President Horst Köhler called 'social responsibility of banks' (Frankfurter Allgemeine, 10/9, p. 33) was their contribution to economic growth and progress through real firm investment (Steinbrück, Deutscher Bundestag, 10/17/2008, p. 19659). The specific focal point of the German debate is the belief that the reason for the crisis lay in the violation of the legitimizing boundary of investment by speculative practices. How did German policymakers translate this persuasion into regulative policy?

\subsection{Back to Sparkasse-regulatory selectivity in the public debate}

The regulatory dimension of the German bailout debate concerned a 're-balanced relation between state and markets' (Steinbrück, Deutscher Bundestag, 10/15/2008, p. 19358) or a 'new order for the market economy' aimed against 'gambling of some bankers' (Struck, faction leader of SPD, Deutscher Bundestag, 10/17/2008, p. 19658). Most statements by public officials and MPs demanded that the bank sector should be forced back to more classical investment. How was this translated into concrete institutional rules? The heart of the image put forward by policymakers and the conservative faction among German bankers is the long-term personal relationship between a bank and a firm.

Being a private bank, we can afford the luxury to think long-term and to invest in people, businesses and the development of new markets without the need to always consider the rate of return first. 
'We are not geared towards profit maximization, we want to support our members and customers throughout the region', says Peter Heinrich, CEO of the Muenchner Bank.

(Sueddeutsche, 10/14, S.S1)

The institutional benchmark for market relations among German policymakers was the Sparkassen and Volksbanken model of locally embedded banking.

Bank clients in Cottbus [small city in Eastern Germany] or in the Ruhr area were not exactly as sexy as the smart traders of London, New York and Hong Kong, with whom it was possible to trade securities that were more and more ludricously constructed, and to cash in equally ludricous salaries and bonuses.

(Stiegler, SPD, Deutscher Bundestag, 10/7/2008, p. 19329)

Also in the press, the Sparkasse was described as a 'refuge of stability in the megacrisis' (Heribert Prantl, Journalist, Sueddeutsche, 10/13, p. 4). German banks that had speculated were perceived to be in urgent need to return to this model. However, the 'model' was defined not in an organizational sense-for example as more decentralization or more co-determination in the troubled banks-but in the sense of a new management paradigm, a benchmark for a legitimate profit strategy for bank managers.

Thus, the issuing of state guarantees for banks had the goal of controlling banks' profit strategies written into it. As Chancellor Merkel put it:

[. . .] the Federal state steps in as insurance for specific liabilities of financial institutes at a certain fee. [ . . .] We have to deal with market excesses. The primary function of the state in a social market economy is control. The state is the guardian of order.

(Deutscher Bundestag, 10/15/2008, p. 19351)

Bringing back order into the market meant as driving out those forms of profit that were believed to damage the stability and growth potential of the German market economy. These coercive goals of the Federal government became clear in the further regulatory details. Beyond the urgent measures of raising liquidity and recapitalization the Minister of Finance presented a set of regulatory reforms that aimed at coercing bank managers out of speculative behaviour. In preparation of the G-7 summit, Steinbrück put emphasis on the idea of limiting short selling (it had been prohibited temporarily by the BaFin on 19th September already) and derivative trading, even mentioning a potential prohibition of it (Deutscher Bundestag, 10/15/2008, p. 19355). Moreover, he argued that the bank bailout law should prevent banks from cutting their balances by not giving out money to SMEs, and it should allow regulators to monitor banks' 'business models'. Similarly, Merkel announced 'obligations concerning the business policies of [financial] institutes' (Deutscher Bundestag, 10/15/ 2008, p. 19350).

Regulation should provide control over the business strategies in German bank headquarters, in which 'evil' speculators were believed to have replaced 'good' firm financiers. Thus, we see a very old cultural stereotype at work here: the juxtaposition of the 'speculator' and the 'entrepreneur' (Sombart, 1915, pp. 87-93). This moral boundary had been an important element of the historical emergence of a class compromise through an 'acceptable German socio-economic ethos' in the early twentieth century (Lange, 2007, p. 15). Although it was historically linked to anti-semitism and radical right wing thought, the separation of 'productive' and 'parasitic' economic action exceeded this context (Loeffler, 2012). In 2008, it was discursively linked to the institutional principles of the German three-tier financial system, with 
the Sparkasse as the clearest image of productive locally embedded firm investment. The financial stability act (Finanzmarktstabilisierungsgesetz) became effective on 17th October 2008. In $\mathbb{1 0}$ of this act the state is endowed with the right to govern the 'business policy [ . . . especially concerning the credit supply to small and medium-sized enterprises, and the sustainability of the pursued business model' which gave regulators unilateral power to coerce the management of bailed out banks.

\subsection{Forgotten context-distorted crisis perception}

It is important to more closely examine what was not discussed in the German debate. The normative focus on the boundary between speculation and investment obscured the domestic structural causes of the crisis, which had evolved over a decade of financial hybridization.

In comparative political economy literature Germany and the UK are usually treated as dichotomous cases of bank-based and market-based financial regimes (Zysman, 1983; Deeg, 1999). In the 'Golden Era' of Post-War mass consumption the German network capitalism was built around 'patient capital', which was provided by house banks in the form of debt. The network aspects were strengthened by a high degree of ownership networks, co-determination and industrial wage setting, as well as high management influence of banks on corporations (Lütz, 1996, pp. 11-12). After the end of the long post-war prosperity period, economic policy became more capital market-friendly. Since 1989, a gradual marketization of German capitalism set in (Beyer and Höpner, 2003), in which the German capital market was deregulated to improve its international competitiveness (Vitols, 2004). Germany became a 'hybrid' system in which new layers of 'US style liberal regulatory institutions' were built atop of the old network structures that remained intact (Vitols, 2003, p. 254). The large German private banks became global players, while the three-tiered financial sector structures and corporate finance showed high institutional resilience (Amable, 2003).

A closer look into the risk exposure of German banks before the crisis of 2008 reveals the high entanglement of German private as well as public banks in the globally dense network of interbank lending and securitization (Table 1).

The public HSH Nordbank announced on 22nd September 2008 that it would suffer a loss of $€ 500$ million due to the Lehman breakdown. The first German private bank in severe trouble was the countries' largest real estate bank, the Hypo Real Estate (HRE). Among other mistakes they had lost $€ 5$ billion in high-risk trading of Irish treasuries.

Moreover, Figures 1 and 2 show that the balance sheet asset structure of German private banks had changed towards interbank lending and less corporate lending since 2000. The German central bank measured the involvement of 14 globally investing large German banks into repo transactions to be $€ 700$ billion (Deutsche Bundesbank, 2009, p. 39), with $€ 450$ billion borne by the four large German banks Deutsche, Commerzbank, Dresdner Bank and Hypovereinsbank (HVB) - roughly a third of their total assets. Figures 1 and 2 also point towards the role of derivatives trading, which has not been part of the official balance-sheets before December 2010.

The German private banks and the public Landesbanken form the largest part of the banking sector. Before the crisis set in at the end of 2007, the German private banking sector had a total asset sum of roughly $€ 6.7$ trillion. It consisted of $€ 2.25$ trillion for private credit banks as a whole, $€ 1.4$ trillion of which can be attributed to the four largest banks, and $€ 1.5$ trillion for the Landesbanken. The Sparkassen who actually showed no relevant changes in their asset structures only provided one sixth of the value of the banking sector in Germany. 
Table 1. Exposure of selected German banks to conduits and special investment vehicles prior to the crisis

\begin{tabular}{llcl}
\hline & Ownership & $\begin{array}{c}\text { In \% of } \\
\text { capital }\end{array}$ & $\begin{array}{l}\text { Conduit- and SIV financed } \\
\text { assets in \% of assets }\end{array}$ \\
\hline Sachsen-Finanzgruppe & Public (Landesbank) & 1126 & 30.3 \\
WestLB & Public (Landesbank) & 542 & 12.7 \\
IKB & Private & 494 & 20.5 \\
Dresdner Bank & Private & 364 & 9.9 \\
Landesbank Berlin & Public (Landesbank) & 179 & 2.2 \\
Bayern LB & Public (Landesbank) & 170 & 5.1 \\
HSH Nordbank & Public (Landesbank) & 126 & 4 \\
Deutsche Bank & Private & 114 & 3.3 \\
HVB & Private & 105 & 6.6 \\
NORD LB & Public (Landesbank) & 89 & 2.9 \\
Commerzbank & Private & 85 & 2.2 \\
Helaba & Public (Landesbank) & 68 & 1.1 \\
DZ-Bank & Private (Co-operative) & 61 & 1.3 \\
LBBW & Public (Landesbank) & 59 & 1.7 \\
KfW & Public & 58 & 2.6 \\
\hline
\end{tabular}

Note: Comparability is limited by different dates and varying definitions.

Source: OECD, Hüfner (2010, p. 5).

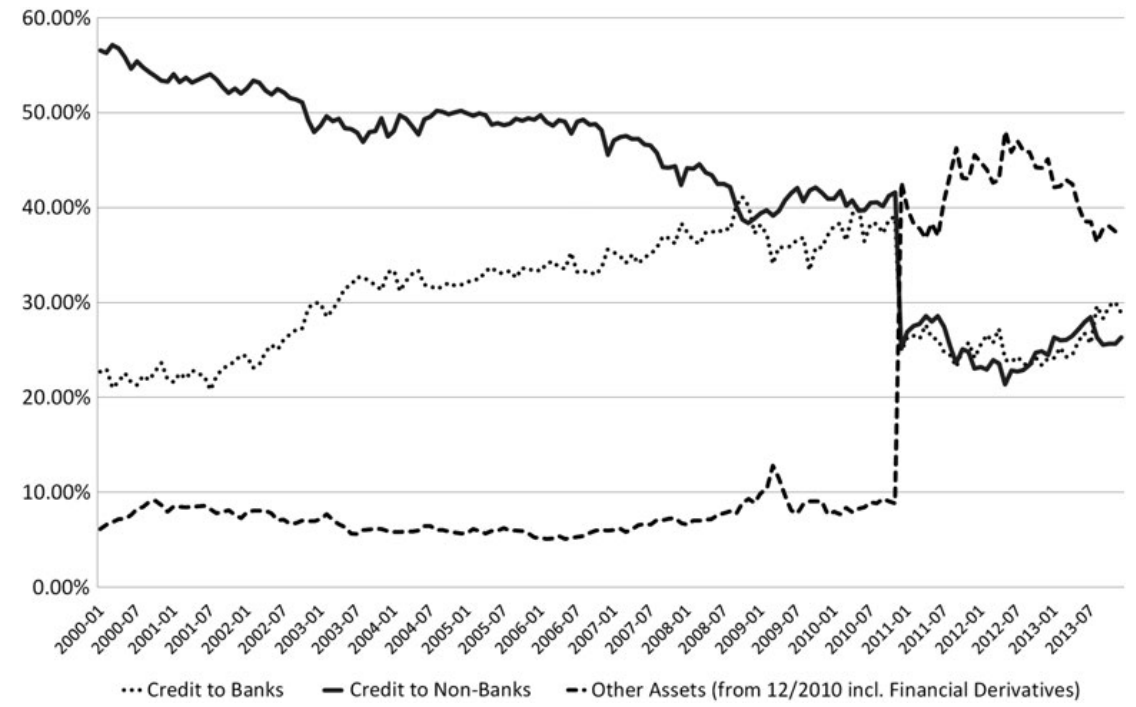

Figure 1. Asset structure of German large private banks 2000-2013.

At least half of the German banking sector was strongly involved in the global securitization and leveraging process-with the Deutsche Bank investment branch being among the top five leverage boomers in the world (Figure 3). 


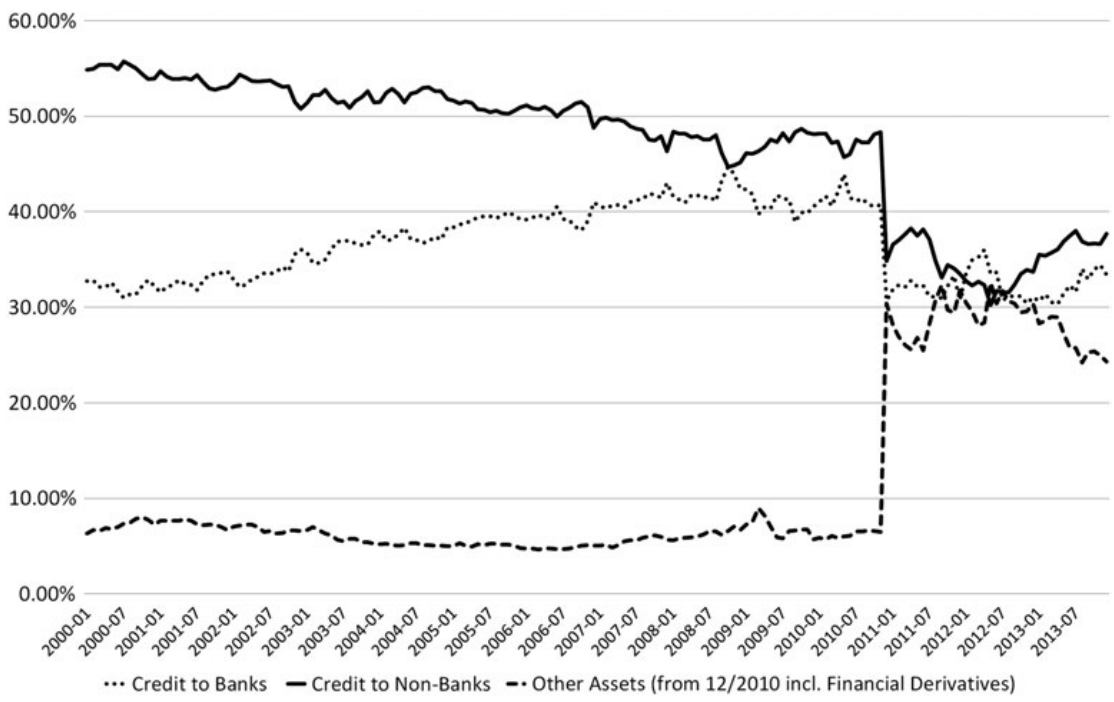

Figure 2. Asset structure of German private credit banks 2000-2013.

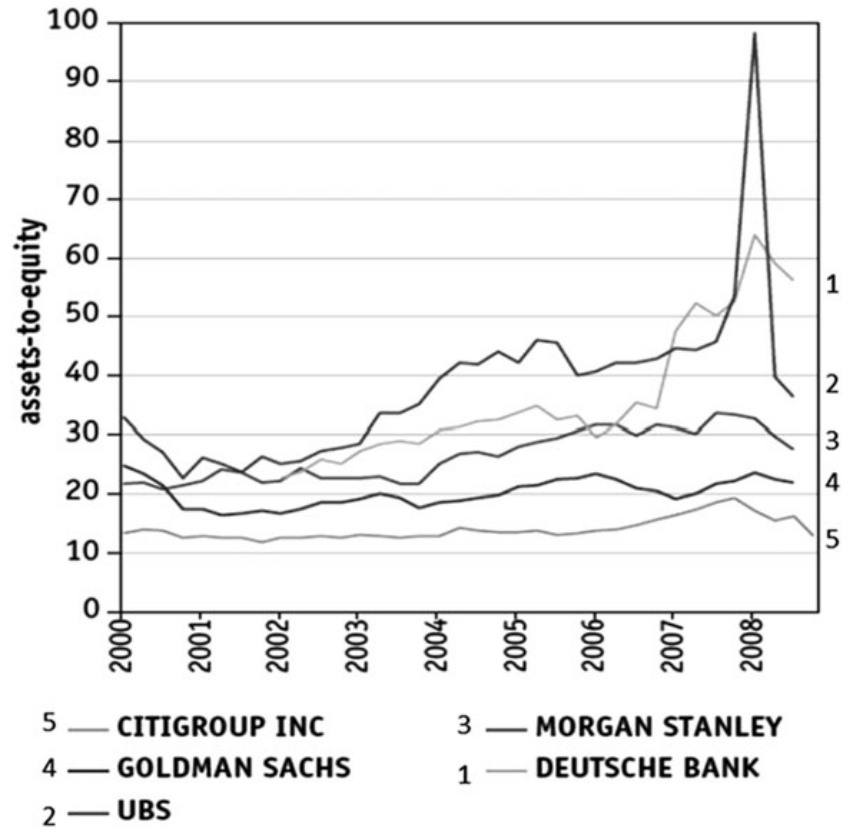

Figure 3. Leverage of largest global investment banks 2000-2008.

Source: Financial Services Authority, 2009b, p. 19. 
While it is difficult to estimate the exact scale of the entanglement of German private and public banks in the global securitization boom, there is evidence that the perception of the German bank sector as built around savings and firm credit in any particularly important way was heavily outdated long before the crisis. Instead of a growing fragmentation between long-term 'investors' and short-term 'speculators', we see that both the private and the public areas of the German banking sector had become vital parts of the global securitization dynamics. In spite of the discursive importance of the Sparkassen image its economic relevance for German industrial capital structure was marginal.

As certain forms of illegitimate profit seeking were seen as the primary cause of the crisis, attention was moved away from the present structural and organizational state of the German banking system. Policymakers did not discuss (a) the structural transformation of large German private banks into global investment banks, (b) the special vulnerability of private savings and firm credit to the repercussions of leverage bubbles in a universal bank system, and (c) the special leverage capacity of public Landesbanken that was rooted in their taxpayer backing, as well as their organizational connection to the Sparkassen. The moral economy of financial profits, which had traditionally accompanied the German three-tier universal banking system, now inhibited a clear view on the domestic structural dimensions of the credit crunch.

\section{Crisis and bailout discourse in the UK}

There are many similarities between the sequence of events at the onset of the crisis in Germany and the UK. In fall 2007, the UK faced a crisis prelude in the imminent breakdown of mortgage securities trader Northern Rock. Already in September 2007, the plummeting of mortgage prices forced Northern rock to borrow $£ 3$ billion from the Bank of England (BoE). This sparked the first British bank-run since 140 years and ruined the domestic housing market. Moreover, after Downing Street had announced that it would guarantee all Northern Rock deposits, more BoE credits had to follow, which added up to $£ 26$ billion in January 2008. After two insufficient private takeover bids, the bank was nationalized in the Banking (Special Provisions) Act in March. Later on, it was split up in a 'good' and a 'bad' bank, after additional loans of $£ 14$ billion had become necessary. After the sale of the good part of Northern Rock the remaining part still owes the government $£ 22$ billion, which could eventually add up to a total loss of $£ 36$ billion.

\subsection{Risk management vs. failure-normative boundaries in the public debate}

Much like in Germany, the first weeks of the British debate were dominated by the idea of 'contagion from the outside'. Failed American house credit policy was blamed, as well as the unwillingness of the US administration to support international financial regulation, as Kevin Livingston, former Labour mayor of London, claimed on 17th September (The Guardian, p. 6). On that same day, the second British step into the crisis was taken, with a huge emergency merger of HBOS and Lloyds TBS, which was financed by a state backed loan of $£ 12$ billion. Still, the British government kept up the contagion thesis throughout September, arguing that ' $[\mathrm{w}]$ hile the problem comes out of America, it has consequences for all of us' (Prime Minister Gordon Brown, Labor Party, The Guardian, 9/26, p. 7). ${ }^{3}$

After 'Black Friday' on 29th September it became clearer that the crisis had domestic origins as well. On that day, the British government announced that the mortgage trader 
Bradford \& Bingley was going to be partially socialized, and the British state would step in for liabilities worth $£ 42.4$ billion. On 1st October, the Financial Services Authority (FSA) started consultations with British banks about higher savings protection. On 6th October, Chancellor Darling announced that the state would do 'whatever is necessary' to secure stability in the banking sector, reacting to the plummeting stock value of RBS and Lloyds TSB, as well as the threat the Icelandic bank-run posed to British bank clients. Finally, on 9th October a package of $£ 50$ billion was offered for the re-capitalization of the seven largest British banks. ${ }^{4}$ Eventually, only Lloyds and RBS sold shares to the government for a total amount of $£ 13.5$ billion. The British government also provided debt guarantees of $£ 450$ billion to boost liquidity in the market.

In October the crisis was re-defined as a 'City problem', with a special focus on illegitimate profits gained by banks over the boom years. The British debate revolved around the individual achievement of financial traders with the key phrase of 'excessive risk-taking'.

Our aim is to support and reward work, enterprise and responsible risk taking, but not irresponsible and excessive risk taking, which has caused so much damage. [ . . ] The Financial Services Authority will soon publish a consultative document about the danger to company balance sheets if, by excessive risk taking, some of their executives put those balance sheets and companies at risk.

(House of Commons, 10/8/2008, cl. 269)

Brown's statement directly aims at the individual practices of financial traders as cause of the crisis. By pointing to work and enterprise he invokes the idea that gains need to be justified by a particular achievement. A 'good' banker will only take on 'responsible risks'. This is explicitly not a systemic statement, but concerns the morality or professional ethos of bankers. The corresponding positive image describes bankers as 'risk entrepreneurs'.

Now everyone agrees about irresponsibility in the financial markets, but let me say, [. . .] the dividing line here is not between business and being anti-business, or between market and being anti-market. The dividing line that we have is between rewarding hard work, effort and responsibility—rewarding enterprise—and rewarding excessive risk-taking or irresponsible risk-taking.

(cl. 269)

In the same debate, Chancellor Darling makes clear that it is not the sum of profits that is criticized, but rather its proportion to individual achievement.

[. . . ] people accept the fact that somebody may be well rewarded for improving the performance of a company or working extremely hard. No one wants to stop that, but we do want to stop situations in which, by accident or as an unintended consequence, people are rewarded for doing things that seriously undermine the financial world.

(House of Commons, 10/8/2008, cl. 172)

Achievement is 'hard work' and the contribution to the 'performance of a company'-this is the core of the entrepreneurial concept of a banker. In contrast to Germany, it is not the

3 In April 2011, Gordon Brown admitted his administration's misperception in the early days of the crisis in a BBC interview: "We set up the FSA believing the problem would come from the failure of an individual institution. That was the big mistake. [. . .] We didn't understand just how entangled things were." (http://www.bbc.co.uk/news/business-13032013).

4 Abbey, Barclays, HBOS, HSBC UK, Lloyds TSB, RBS, Standard Chartered, and the large mortgage trader Nationwide. 
economic performance or capital gain of an industrial company financed by the investor that entitles him to a profit share, but it is the success of the financial actor in effectively and successfully managing risk (House of Commons, 10/13/2008, cl. 548). Profits are illegitimate if they are gained without a special intellectual capacity or achievement in risk management, in the worst case endangering the company or the whole market.

Brown also blamed the people who were supposed to control traders and monitor the risktaking, doubting how 'effective' (House of Commons, 10/6/2008, cl. 23) they were and if they actually understood what they were doing.

It is really quite extraordinary that boards themselves did not more fully understand what risks they were allowing their banks to become exposed to. The first line of defense, not just for shareholders but for everyone else, is to make sure boards are up to the job.

(Gordon Brown, The Guardian, 10/14, p. 1)

Brown claims a moral responsibility for bankers and their supervisors to rationally calculate their investments. This is supposed to be their special capacity for which they may legitimately claim profits.

His perspective was shared across political camps. Conservative shadow Chancellor George Osborne also used the phrase 'reward for failures' to pin down the causes of the crisis (The Guardian, 10/14, p. 7). In the parliamentary debate on the 6th of October he argued that 'banks that pay out dividends instead of rebuilding balance sheets should be held to account by regulators' (House of Commons, 10/6/2008, cls. 24-25).

There should not be rewards for failure — no bonuses for those who took their banks to the edge of bankruptcy.

(The Guardian 10/10, p. 1)

In the British debate, the idea that greed had taken over the behaviour of bank professionals accuses the bankers of irrationality or incompetence, not of egoism, like in Germany. Policymakers were joined by many public commentators in this estimation. To cite just two: Deborah Hargreaves, Guardian's business editor, called for firing the bosses (The Guardian, 10/10/08, p. 34). Her Daily Telegraph colleague Bill Emmott demanded that 'boards should be sacked, fraudsters punished and shareholders made to suffer' (Daily Telegraph, 10/04/08, p. 28). It is not the lack of real economy investment in their practices that is at the heart of the critique, but their poor speculative achievement, their lack of the supposedly scarce capacity of calculating, managing, and eventually absorbing 'natural' economic risks.

\subsection{No rewards for failure-regulatory selectivity in the public debate}

Regulatory action beyond the immediate liquidity boost and re-capitalization was very different in UK bailout laws. MPs from both sides of the House were primarily worried about a possible 'moral hazard' of bailout policies if public money was used for financing bonuses and shareholder dividends.

[. . . ] and we could not contemplate taxpayers' money being used to prop up the kind of salaries and bonuses that we have seen.

(George Osborne, Conservative Shadow Chancellor, House of Commons 10/6/2008, cl. 24) 
Beyond the bailed out banks, executive remuneration was considered the most important aspect of future regulation, which was inevitable for the prevention of future crises.

We want to ensure that firms follow remuneration policies which are aligned with sound risk management systems and controls [. . . ].

(FSA press statement, The Guardian, 10/14, p. 7)

Brown also announced that the FSA will regulate executive remuneration in the implementation of the bailout laws

It [FSA capital adequacy ruling] will take into account whether firms are taking excessive risk by rewarding people on the basis of short-term gains, not long-term success.

(House of Commons 10/8/2008, cl. 270)

Again, his opinion was shared by the conservatives and the liberals in the house, with David Cameron claiming: '[. . . ] no more irresponsible behaviour, no more inappropriate dividend policies and no more indefensible bonus packages' (House of Commons 10/8/2008, p. 269).

Like in Germany, political leaders were supported by the wider public, which criticized 'City bonus culture' (The Guardian, 09/26/08, p. 37; 10/14, p. 7). The argument was coined by union activists as well as representatives of financial professions.

We take the rather old-fashioned view that bankers, like the vast majority of people at work, should be paid a proper wage for doing a good job, and should not require bonuses to get up in the morning.

(Brendan Barber, TUC, The Guardian, 10/14, p. 7)

Remuneration and incentivisation packages for senior figures within the banking world have rocketed, but these rewards have become too closely linked to short-term, easy-to-manipulate financial metrics.

(Richard Aitken-Davies, President of the Association of Chartered Certified Accountants, The Guardian, 10/6/08, p. 39, see also: Alternative Investment Management Association, Daily Mail, 10/15/08, p. 6)

While sharing a common focus, the topic still was an arena for party struggle. When the conservatives were urging the government to cut bonuses in the nationalized banks Brown and Darling accused the conservatives of not differentiating between legitimate and illegitimate bonuses accurately and demotivating even 'good' bankers with a general cut (House of Commons, 10/8/2008, cl. 274). The liberal democrats followed this perspective and called for more meritocratic schemes and the sustained need of bonuses for rewarding outstanding achievements (Jeremy Browne, Liberal Democrats, House of Commons 10/9/2008, p. 441).

The British bonus debate shows the strong belief of British policymakers that the regulatory authorities FSA and BoE would be able to step in and 'do the jobs banks usually do' (Gordon Brown, House of Commons, 10/8/2008, cl. 269). The positive model of finance described running a bank along the principles of effective risk-management and achievement-related pay. The shared narrative of the UK crisis held excessive risk-taking of traders responsible for the bubble. This also meant a failure at their primary professional task, for which they legitimately claim profits, and a failure of managers and board to set pay incentives for a high performance.

Similarly to Germany, the crisis explanation was filtered by a normative boundary between legitimate and illegitimate profits. In the British context, however, this boundary was defined 
along the discursive separation of risk bearing and excessive gambling that has been described by de Goede as the primary legitimizing root of modern finance in the UK and the US (de Goede, 2005, pp. 81-85). The normative definition of legitimate profits in the British bailout debate is marked by the superior rationality and professional skills of financial traders to estimate and calculate economic risks. Again, like in Germany, this moral boundary was deeply intermingled with the national institutional regime. In the UK debate, legitimate financial profits required free and transparent market competition as a safeguard for achievement-related pay and the punishment of inaccurate risk calculation. Therefore, regulation sought to replace underperforming boards with state administrators and alter the payment structure of the sector towards meritocratic market principles.

\subsection{Forgotten context-the distortion of the crisis perception}

It is now necessary to look closer at the economic dimensions of the UK banking crisis to see the degree of ideational filtering present in the crisis perception. The British financial sector became heavily leveraged over the boom years. As Figure 4 shows the capital structure of British financial firms was strongly dominated by securities since 2003 peaking at $49.3 \%$ before the Lehman breakdown.

The leverage ratio of British banks (assets to equity) was raised from 8 to 20 between 2003 and 2008. Leverage was even more dramatic if ratio spreads between the largest banks are considered (Figure 5).

Beyond the striking importance of leverage in the UK, there is also evidence that raises doubt on the argument that traders' aspirations alone provided the primary cause for the crisis. The British financialization boom was fueled by a steep increase in the indebtedness of private households, with a growing degree of securitized loans in mortgage lending. Outstanding debt in mortgage increased to $80 \%$ of GDP in 2007 and the median proportion of income paid for mortgage contracts went up to $19 \%$ before the onset of the crisis (FSA, $2009 a, b$, p. 30). The British population as well as British corporations were drawn into the bubble as much as the traders (Figure 6).

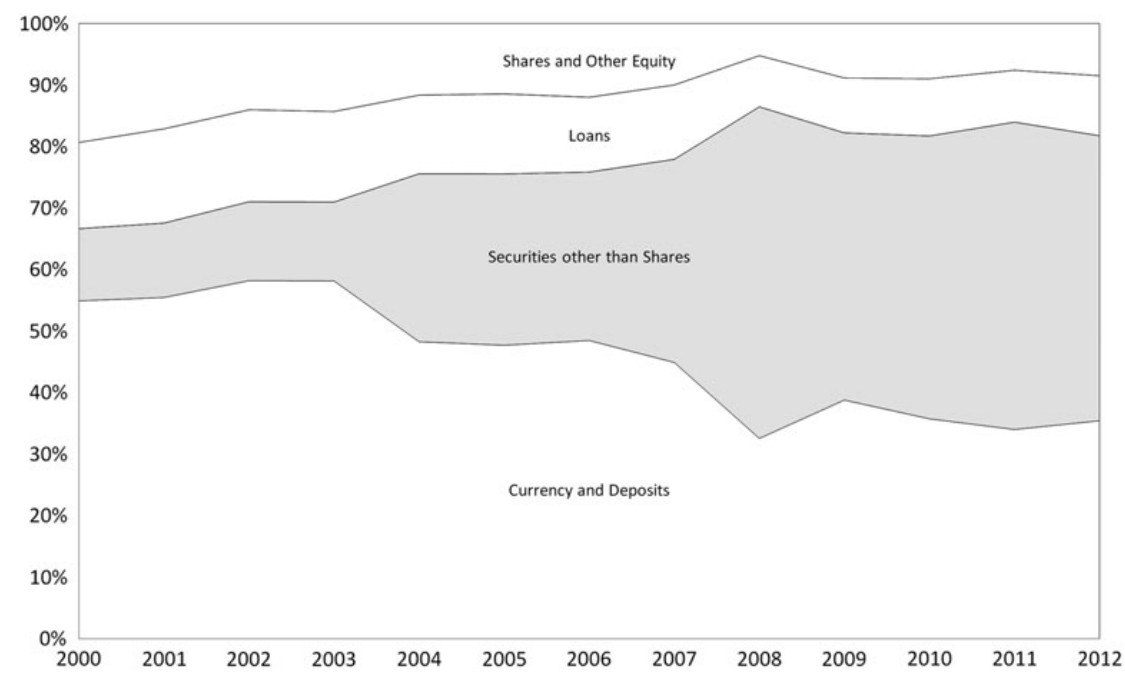

Figure 4. UK Financial corporations-liabilities 2000-2012. 


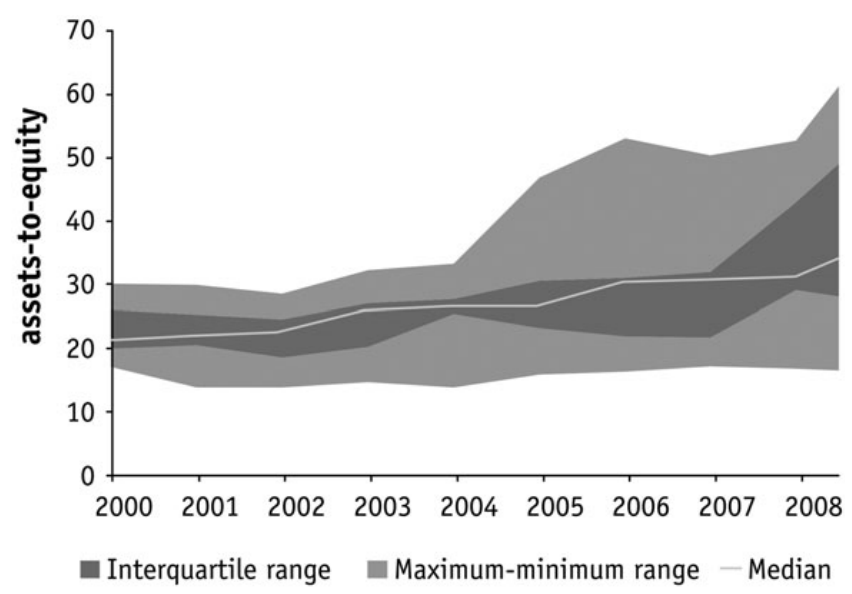

Figure 5. Leverage largest UK banks 2000-2008.

Source: Financial Services Authority, 2009, p. 19.

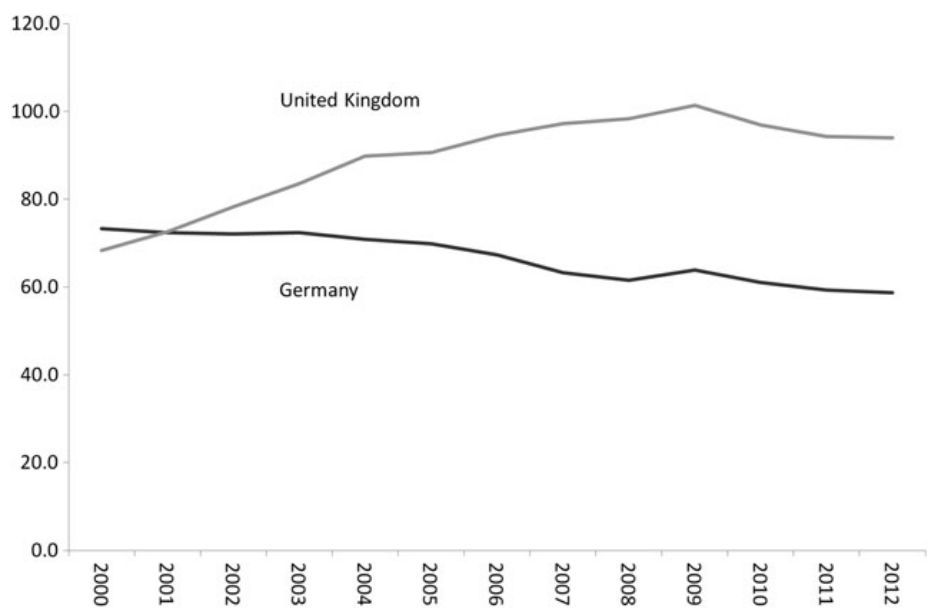

Figure 6. Household debt to GDP (\%), UK 2000-2012.

Finally, there is reason to doubt that remuneration practices played a major role for the explosion of leverage. Indeed, top management bonuses were high. The top three executives of Northern Rock and Banford \& Bingleys received a sum of $£ 4.4$ million resp. $£ 2.2$ million, with more than a half of it going to the CEO (Chen et al., 2011). However, generally speaking, the bonus part in top executive payments was proportionate to the profits raised by the banks in the boom. RBS paid out bonuses to their top three executives of $£ 2$ million for 2007, mirroring a net annual profit of $£ 7.7$ million. Northern Rock, facing a loss in 2007 , did not pay out any bonuses. This would suggest that blaming the remuneration structures actually overlooks the fact that the financial firms, their depositors and shareholders were gaining as much profit out of the leveraging boom as the traders. Accordingly, economic models have 
shown that high risk taking is in line with shareholder interests as long as the traders engage in the trading of low risk class of financial products-which most of the market actors believed they were doing in the boom (Franke and Krahnen, 2008, p. 28). However, if real risks later turn out to have been much higher, they are externalized from executives to shareholdersand eventually to the taxpayer-because of the impossibility of bonuses falling below zero. Therefore, there is a conflict of interest between traders and the firm-but only if the crisis is already there. The option to 'dance until the music stops' was attractive for traders, shareholders, and asset-holders alike, expanding into large parts of UK consumers and firms. Even though an FSA study on remuneration practices in 2009 showed that very often bonuses in UK banks were not adequately aligned with risk-sensitive indicators (FSA, 2009a, b, p. 16), the FSA concluded that bonus incentives were a minor aspect within a larger context of unmonitored leveraging in the UK.

It is not possible to prove a direct causal link between remuneration practices and the market crisis. Other factors such as over-ambitious strategies, over-reliance on third party risk assessment, and herd-like behaviour by firms are likely to have been more important.

$$
\text { (FSA, 2009a, b, p. 14) }
$$

Still, remuneration practices remained at the centre of the British regulatory efforts. The Treasury Committee hosted hearings and published a special report on remuneration practices, with a remarkable reaction to the FSA Turner Review:

The Turner Review downplays the role that remuneration structures played in causing the banking crisis [. . .]. Such a stance sends out the wrong signals and will only serve to encourage some within the banking sector to believe that they have a green light to continue with the same discredited remuneration practices [. . .] there is a legitimate public interest in the way in which the structure of remuneration packages might create incentives for particular types of behaviour. (HoC Treasury I, 2009, p. 16)

If the causal relevance of remuneration cannot be upheld any longer, the matter is now framed as 'legitimate public interest' in ending 'discredited practices'. It seems that, if confronted with counterevidence, the normative background of the crisis narrative comes to the full forefront. The British government backed up the committee against the FSA in a similar way: 'The Government recognises the public's view on the issue of salaries and bonuses awarded in the banking sector' (HoC Treasury II 2009, p. 4). Thus, regulatory emphasis remained on the remuneration issue. In April 2009 remuneration reports became obligatory for all companies and in July 2009 the FSA was given wider power to adjust capital requirements for banks, if they fail to meet the new Code of Conduct requiring 'remuneration policies, procedures and practices that are consistent with and promote effective risk management' (FSA, 2009a, b, p. 28).

The empirical material has demonstrated that the regulatory focus on the bonus issue was driven by a crisis perception that was normatively filtered with the idea that profits should be an achievement-related pay for successful risk management. The crisis was believed to have been caused by incompetent traders, managers, boards and credit agencies, who had focused more on their individual bonuses than on rational risk management. With this focus, however, domestic market structures were dropped out of sight. Not discussed were (a) the enormous leverage problems faced by all sectors and households of the British economy, and (b) the fact that the leveraging process had been driven by shareholders, corporations and bank clients alike. 
Like in Germany, the normative boundary of legitimate profits was intimately linked to the organizational core of the British financial regime. The idea that a functioning market will only remunerate those who have a special capacity to estimate risks correctly and prevail in market competition had an affinity to British market structures. It supported free market exchange and competition as a safeguard for meritocratic payment and highly rational risk management.

\section{Conclusion}

In this article I argued that the lack of fundamental change in European financial market regulation does not render obsolete the conceptual claim that policymakers and administrators have an autonomous capacity to define and push through their definition of the national interest in a time of crisis. I have defended that claim by showing that the lack of fundamental restructuring can be understood as autonomous state action, in which policymakers followed a crisis narrative that was shaped by normative ideas about legitimate financial profits. This narrative had a high affinity to the distinct institutional core principles of the two financial regimes. Facing uncertainty at the onset of the crisis, policymakers oriented their crisis perception along the assumption that it had been caused by financial actors pursuing illegitimate, immoral forms of profit. Policymakers and public commentators from all camps in Germany agreed that the crisis had been caused by bankers engaging with speculative activities rather than providing real economy investment. In the British debate, a major cause of the crisis was seen in traders gaining profits without being able to secure an effective management of economic risks. This moral filtering of the public debates left policymakers blind for the domestic structural and organizational dimensions of the crisis in both countries. The core problem of the boom years was the explosion of leverage and a growing interdependence of all financial corporations. For both countries, this meant that the largest parts of their financial sectors had been fully engaged in or even driven the international securitization process. Therefore, there would have been reasons to suspect that the core organizational principles of both national financial systems, universal and public banks in Germany, free market access and competitive financing in the UK, were in need of reform.

However, the moral boundaries that distorted the political learning process had a strong affinity to core institutional principles of the two distinct financial regimes. 'Non-speculative investment' was equaled to the regulatory principle of universal banks and Sparkassen in Germany, and 'risk-management' and meritocratic distribution of profits were tied to free competition and transparency in the financial market in UK. Transferring their moralized crisis narrative into regulatory effort, German policymakers ended up trying to reorient the Deutsche Bank into a large scale version of a Sparkasse, ignoring the fact that it had irreversibly developed into a financial derivatives trader, with the public Landesbanken heavily engaged in the same process. In the UK, cutting bonuses and holding boards responsible became the institutional safeguard for achievement-related pay that would then force traders to return to the rational calculation and management of risks. This meant ignoring the fact that free market access and competition for interest rates had not provided any protection against systemic bubble dynamics, herd effects and unmanaged systemic risk. In both countries, the crisis eventually led to a re-affirmation of core principles of national bank systems as the best regulatory answer to the crisis. It was both the plausible and morally legitimate response. The fact that a state administration more powerful than long before limited 
regulatory change to marginal scope can therefore be explained by policymakers from all different camps looking at the crisis through the lenses of their national political cultures, in which moral boundaries of legitimate profit seeking are synonymous with the core principles of the institutional status quo, and change takes on the character of 'readjustment'.

In contrast to recent ideational works on the crisis, I am not focusing on the resilience of economic policy paradigms such as liberalism or austerity (Blyth, 2013a) but point to the affinity of existing institutions and the public morality of financial markets as a source of institutional resilience. My argument could be seen as complementary: where Schmidt and Thatcher cite the embedding of neoliberal ideas into market institutions as one source of resilience (2013, p. 2) I stress that institutions embed moral critique of capitalism, which makes the re-affirmation of the institutional status quo always a strong and valid discursive response to the failure of liberalized markets. I think that it could be very fruitful for future debates among ideational researchers to differentiate levels of discourse and ask how market institutions mediate between professional economic knowledge, political legitimacy and public moral economy.

In the debates analyzed here, it has become clear that, for policymakers facing the pressure of an imminent crisis, morality and institutional principles are inseparable. Policymakers talk and argue institutions-even where they want to change them. However, the tightness of this entanglement of morality and institutions depends on the level of regulatory content of an institution: the basic organizational principles have a high affinity with ideas of legitimate economic action in national political cultures. Therefore, they are more likely be out of dispute, while concrete patterns of governance and detailed institutional rules can be subject to change. Path-breaking government action will often be framed as containment of economic practices that contradict the 'original purpose' of the institution and caused the current crisis. This can help us to understand why institutional change, even if it is triggered by an international economic crisis, will rather tend to further evolve along a national trajectory than lead to convergence of different market regimes. The historically grown affinity between the core structures of market regulation and their moral justification in political discourse is an important source of institutional stability for any capitalist market order, particularly in a 'dangerous' moment of high autonomy of a democratic state. It provides legitimacy to the status quo beyond its economic functionality. Once again, capitalism is saved by its public critique.

\section{Acknowledgements}

The research for this article was generously supported by the Max-Planck-Institute for the Study of Societies, Cologne, Germany, as well as by the Minda de Gunzburg Center for European Studies, Harvard University, Cambridge, USA. The author thanks Göran Köber, Aura-Shirin Riedel and Sandra Vietgen for their indispensable support. Many thanks to an extraordinarily committed editor, as well as three anonymous and very helpful reviewers. Additional thanks for helpful comments to Jürgen Kädtler, Helen Callaghan and my fellow visiting scholars at the CES on earlier versions of this article.

\section{References}

Amable, B. (2003) The Diversity of Modern Capitalism, Oxford, Oxford University Press.

Beckert, J. (2010) 'Institutional Isomorphism Revisited. Convergence and Divergence in Institutional Change', Sociological Theory, 2, 150-166.

Benford, R. D. and Snow, D. A. (2000) 'Framing Processes and Social Movements. An Overview and Assessment', Annual Review of Sociology, 26, 611-639. 
Berman, S. (2013) 'Ideational Theorizing in the Social Sciences Since "Policy Paradigms, Social Learning, and the State", Governance, 2, 217-237.

Beyer, J. and Höpner, M. (2003) 'The Disintegration of Organised Capitalism: German Corporate Governance in the 1990s', West European Politics, 4, 179-198.

Blyth, M. (2002) Great Transformations. Economic Ideas and Institutional Change in the Twentieth Century, Cambridge, Cambridge University Press.

Blyth, M. (2013a) Austerity. The History of a Dangerous Idea, Oxford, Oxford University Press.

Blyth, M. (2013b) 'Paradigms and Paradox: The Politics of Economic Ideas in Two Moments of Crisis', Governance, 2, 197-215.

Braun, D. (1999) 'Interests or Ideas? An Overview of Ideational Concepts in Public Policy Research'. In Braun, D. and Busch, A. (eds) Public Policy and Political Ideas, Cheltenham and Northampton, Edward Elgar, pp. 11-29.

British Parliament, House of Commons. (10/6/2008) 'House of Commons Debates 6 October 2008. House of Commons', Parliamentary Debates (Hansard), 480, 139.

British Parliament, House of Commons. (10/8/2008) 'House of Commons Debates 8 October 2008. House of Commons', Parliamentary Debates (Hansard), 480, 141.

British Parliament, House of Commons. (10/9/2008) 'House of Commons Debates 9 October 2008. House of Commons', Parliamentary Debates (Hansard), 480, 142.

British Parliament, House of Commons. (10/13/2008) 'House of Commons Debates 13 October 2008. House of Commons', Parliamentary Debates (Hansard), 480, 143.

British Parliament, House of Commons, Treasury Committee, HoC Treasury II. (2009) 'Banking Crisis: Reforming Corporate Governance and the Pay in the City', Government, UK Financial Investments Ltd and Financial Services Authority Responses to the Ninth Report from the Committee, available online at: http://www.publications.parliament.uk/pa/cm200809/cmselect/ cmtreasy/519/51912.htm, Accessed 19 June 2015.

British Parliament, House of Commons, Treasury Committee, HoC Treasury I. (2009) 'Banking Crisis: Reforming Corporate Governance and the Pay in the City', Ninth Report of Session 2008-09, available online at: http://www.publications.parliament.uk/pa/cm200809/cmselect/cmtreasy/519/519.pdf, Accessed 19 June 2015.

Campbell, J. L. (2004) Institutional Change and Globalization, Princeton, Princeton University Press.

Chen, J. J., Zhang, H., Xiao, X. and Li, W. (2011) 'Financial Crisis and Executive Remuneration in Banking Industry-An Analysis of Five British Banks', Applied Financial Economics, 23, 1779-1791.

Culpepper, P. D. and Reinke, R. (2014) 'Structural Power and Bank Bailouts in the United Kingdom and the United States', Politics \& Society, 4, 427-454.

Deeg, R. (1999) Finance Capitalism Unveiled. Banks and the German Political Economy, Ann Arbor, University of Michigan Press.

Deutsche Bundesbank. (2009) Finanzstabilitätsbericht 2009.

Deutscher Bundestag. (9/25/2008) Stenografischer Bericht. 179. Sitzung 16/179.

Deutscher Bundestag. (10/7/2008) Stenografischer Bericht. 181. Sitzung 16/181.

Deutscher Bundestag. (10/15/2008) Stenografischer Bericht. 182. Sitzung 16/182.

Deutscher Bundestag. (10/17/2008) Stenografischer Bericht. 184. Sitzung 16/184.

DiMaggio, P. J. and Powell, W. W. (1991) 'The Iron Cage Revisited. Institutional Isomorphism and Collective Rationality in Organizational Fields'. In Powell, W. W. and DiMaggio, P. J. (eds) The New Institutionalism in Organizational Analysis, Chicago/London, University of Chicago Press, pp. 63-82.

Evans, P., Rueschemeyer, D. and Skocpol, T. (eds) (1985) Bringing the State Back In, New York, Cambridge University Press.

Financial Services Authority. (2009a) 'Reforming Remuneration Practices in Financial Services. FSA', Consultation Paper, 10, available online at: http://www.fsa.gov.uk/pubs/cp/cp09_10.pdf, Accessed 19 June 2015. 
Financial Services Authority. (2009b) 'The Turner Review: A Regulatory Response to the Global Banking Crisis. FSA', available online at: http://www.fsa.gov.uk/pubs/other/turner_review.pdf, Accessed 19 June 2015.

Fligstein, N. (1996) 'Markets as Politics. A Political-Cultural Approach to Market Institutions', American Sociological Review, 8, 656-673.

Fourcade, M., Steiner, P., Streeck, W. and Woll, C. (2013) 'Moral Categories in the Financial Crisis', Socio-Economic Review, 3, 601-627.

Franke, G. and Krahnen, J. P. (2008) The Future of Securitization, Frankfurt am Main, Center for Financial Studies.

de Goede, M. (2005) Virtue, Fortune, and Faith. A Genealogy of Finance, Minneapolis, MN, University of Minnesota Press, University Presses Marketing, distributor, Bristol (Borderlines, v. 24).

Goldstein, J. and Keohane, R. (1993) 'Ideas and Foreign Policy. An Analytical Framework'. In Goldstein, J. and Keohane, R. (eds) Ideas and Foreign Policy. Beliefs, Institutions, and Political Change, Ithaca/London, Cornell University Press, pp. 3-30.

Gorton, G. (2010) Slapped by the Invisible Hand. The Panic of 2007, Financial Management Association Survey and Synthesis Series, Oxford, NY, Oxford University Press.

Graeber, D. (2011) Debt. The First 5,000 Years, Brooklyn, NY, Melville House.

Grossman, E. and Woll, C. (2014) 'Saving the Banks: The Political Economy of Bailouts', Comparative Political Studies, 4, 574-600.

Hacker, J. S. (2004) 'Privatizing Risk without Privatizing the Welfare State. The Hidden Politics of Social Policy Retrenchment in the United States', American Political Science Review, 2, 243-260.

Hall, P. A. (1989a) 'Conclusion. The Politics of Keynesian Ideas'. In Hall, P. A. (ed.) The Political Power of Economic Ideas. Keynesianism Across Nations, Princeton, Princeton University Press, pp. 361-391.

Hall, P. A. (ed.) (1989b) The Political Power of Economic Ideas. Keynesianism Across Nations, Princeton, Princeton University Press.

Hall, P. A. (1993) 'Policy Paradigms, Social Learning, and the State. The Case of Economic Policymaking in Britain', Comparative Politics, 25, 275-296.

Hall, P. A. (2013) 'Commentary: Brother, Can You Paradigm?', Governance, 2, 189-192.

Hall, P. A. and Taylor, R. C. (1996) 'Political Science and the Three New Institutionalisms', MPIFG Discussion Paper 6, Max-Planck-Institut für Gesellschaftsforschung, Köln.

Heclo, H. (1974) Modern Social Politics in Britain and Sweden. From Relief to Income Maintenance, New Haven/London, Yale University Press.

Hirschman, A. O. (1986) 'Against Parsimony. Three Easy Ways of Complicating Some Categories of Economic Discourse'. In Hirschman, A. O. (ed.) Rival Views of Market Society and Other Recent Essays, New York, Viking, pp. 142-160.

Hüfner, F. (2010) 'The German Banking System: Lessons from the Financial Crisis'. Edited by OECD, Economics Department Working Papers 788, Paris, OECD, available online at: http://dx.doi.org/ 10.1787/5kmbm80pjkd6-en, Accessed 19 June 2015.

Jenkins-Smith, H. C. and Sabatier, P. A. (1993) 'The Dynamics of Policy-Oriented Learning'. In Sabatier, P. A. and Jenkins-Smith, H. C. (eds) Policy Change and Learning. An Advocacy Coalition Approach, Boulder, Colorado, Westview Press, pp. 41-56.

Lange, M. (2007) Antisemitic Elements in the Critique of Capitalism in German Culture, 18501933, Oxford, New York, Peter Lang.

Lessenich, S. (2005) 'Frozen Landscape' Revisited: Path Creation in the European Social Model', Social Policy and Society, 4, 345-358.

Loeffler, M. C. (2012) 'Producers and Parasites: The Critique of Finance in Germany and Britain, 1873-1933', Dissertation, University of Chicago. 
Lütz, S. (1996) 'The Revival of the Nation-State? Stock Exchange Regulation in an Era of Internationalized Financial Markets’, MPIfG Discussion Paper, 96, 9, Max-Planck-Inst. für Gesellschaftsforschung, Köln.

Mayntz, R. (2013) 'Financial Market Regulation in the Shadow of the Sovereign Debt Crisis', MPIfG Discussion Paper 13/11, Max-Planck-Institute for the Study of Societies, Köln.

Meyer, J. W. and Rowan, B. (1991) 'Institutionalized Organizations. Formal Structure as Myth and Ceremony'. In Powell, W. W. and DiMaggio, P. J. (eds) The New Institutionalism in Organizational Analysis, Chicago/London, University of Chicago Press, pp. 41-62.

Palier, B. (2005) 'Ambiguous Agreement, Cumulative Change: French Social Policy in the 1990s'. In Streeck, W. and Thelen, K. (eds) Beyond Continuity. Institutional Change in Advanced Political Economies, Oxford, Oxford University Press, pp. 127-144.

Ringe, N. (2005) 'Policy Preference Formation in Legislative Politics. Structures, Actors, and Focal Points', Annual Review of Political Science, 4, 731-745.

Schmidt, V. A. (2008) 'Discoursive Institutionalism. The Explanatory Power of Ideas and Discourse', Annual Review of Political Science, 11, 303-326.

Schmidt, V. A. (2010) 'Taking Ideas and Discourse Seriously: Explaining Change Through Discursive Institutionalism as the Fourth 'New Institutionalism”, European Political Science Review, 1, 1-25.

Schmidt, V. A. and Thatcher, M. (2013) 'Theorizing Ideational Continuity. The Resilience of Neo-liberal Ideas in Europe'. In Schmidt, V. A. and Thatcher, M. (eds) European Political Economy. Resilient Liberalism Through Boom and Bust, Contemporary European Politics, Cambridge, Cambridge University Press, pp. 1-52.

Schutz, A. (1962) 'Common Sense and Scientific Interpretation of Human Action'. In Schutz, A. (ed.) Collected Papers, The Hague, Nijhoff.

Skocpol, T. and Finegold, K. (1982) 'State Capacity and Economic Intervention in the Early New Deal', Political Science Quarterly, 2, 255-278.

Sombart, W. (1915) The Quintessence of Capitalism. A Study of the History and Psychology of the Modern Business Man, translated and edited by M. Epstein, New York, E.P. Dutton \& Co.

Steinmetz, G. (1993) Regulating the Social. The Welfare State and Local Politics in Imperial Germany, Princeton, Princeton University Press.

Streeck, W. and Thelen, K. (2005) 'Introduction. Institutional Change in Advanced Political Economies'. In Streeck, W. and Thelen, K. (eds) Beyond Continuity. Institutional Change in Advanced Political Economies, Oxford, Oxford University Press, pp. 1-39.

Swidler, A. (1986) 'Culture in Action. Symbols and Strategies', American Sociological Review, 51, 273-286.

Thelen, K. (2003) 'How Institutions Evolve. Insight from Comparative Historical Analysis'. In Mahoney, J. and Rüschemeyer, D. (eds) Comparative Historical Analysis in the Social Sciences, Cambridge, Cambridge University Press, pp. 208-240.

Vitols, S. (2003) 'From Banks to Markets. The Political Economy of Liberalization of the German and Japanese Financial Systems'. In Yamamura, K. and Streeck, W. (eds) The End of Diversity? Prospects for German and Japanese Capitalism, Cornell Studies in Political Economy. Ithaca, Cornell University Press, pp. 240-260.

Vitols, S. (2004) 'Changes in Germany's Bank-Based Financial System. A Varieties of Capitalism Perspective', Discussion Paper SP II 03, Wissenschaftszentrum Berlin, Berlin.

Weir, M. and Skocpol, T. (1985) 'State Structures and the Possibilities for "Keynesian” Responses to the Great Depression in Sweden, Britain, and the United States'. In Evans, P., Rueschemeyer, D. and Skocpol, T. (eds) Bringing the State Back In, New York, Cambridge University Press, pp. 107-163.

Zysman, J. (1983) Governments, Markets, and Growth. Financial Systems and the Politics of Industrial Change, Cornell studies in Political Economy. Ithaca, Cornell University Press. 